THE IMPACT OF A PEOPLE'S REPUBLIC OF CHINA SLOWDOWN ON COMMODITY PRICES AND DETECTING THE ASYMMETRIC RESPONSES OF ECONOMIC ACTIVITY IN ASIAN COUNTRIES TO COMMODITY PRICE SHOCKS

Atanu Ghoshray and Madhavi Pundit

NO. 493

July 2016
ADB ECONOMICS WORKING PAPER SERIES 
ADB Economics Working Paper Series

\section{The Impact of a People's Republic of China Slowdown on Commodity Prices and Detecting the Asymmetric Responses of Economic Activity in Asian Countries to Commodity Price Shocks}

Atanu Ghoshray and Madhavi Pundit

No. 493 | July 2016
Atanu Ghoshray (atanu.ghoshray@ncl.ac.uk) is professor of economics at the Newcastle University Business School, Newcastle-upon-Tyne. Madhavi Pundit (mpundit@adb.org) is an economist at the Economic Research and Regional Cooperation Department, Asian Development Bank.

The involvement of Atanu Ghoshray in the preparation of this working paper has been in his personal capacity. The opinions expressed in this article are the author's own and do not reflect the views of the Newcastle University Business School. 
(C) 2016 Asian Development Bank

6 ADB Avenue, Mandaluyong City, 1550 Metro Manila, Philippines

Tel +632632 4444; Fax +6326362444

www.adb.org

Some rights reserved. Published in 2016.

Printed in the Philippines.

ISSN 2313-6537 (Print), 2313-6545 (e-ISSN)

Publication Stock No. WPS168300-2

Cataloging-In-Publication Data

Asian Development Bank.

The Impact of a People's Republic of China slowdown on commodity prices and detecting the asymmetric responses of economic activity in Asian countries to commodity price shocks.

Mandaluyong City, Philippines: Asian Development Bank, 2016.

1. Commodity prices. 2. Economic growth. 3. Flexible fourier form. 4. Impulse response analysis. 5. PRC slowdown. I. Asian Development Bank.

The views expressed in this publication are those of the authors and do not necessarily reflect the views and policies of the Asian Development Bank (ADB) or its Board of Governors or the governments they represent.

ADB does not guarantee the accuracy of the data included in this publication and accepts no responsibility for any consequence of their use. The mention of specific companies or products of manufacturers does not imply that they are endorsed or recommended by ADB in preference to others of a similar nature that are not mentioned.

By making any designation of or reference to a particular territory or geographic area, or by using the term "country" in this document, $A D B$ does not intend to make any judgments as to the legal or other status of any territory or area.

This work is available under the Creative Commons Attribution 3.0 IGO license (CC BY 3.0 IGO)

https://creativecommons.org/licenses/by/3.0/igo/. By using the content of this publication, you agree to be bound by the terms of this license.

This CC license does not apply to non-ADB copyright materials in this publication. If the material is attributed to another source, please contact the copyright owner or publisher of that source for permission to reproduce it. ADB cannot be held liable for any claims that arise as a result of your use of the material.

Attribution - In acknowledging ADB as the source, please be sure to include all of the following information:

Author. Year of publication. Title of the material. (c) Asian Development Bank [and/or Publisher].

URL. Available under a CC BY 3.0 IGO license.

Translations-Any translations you create should carry the following disclaimer:

Originally published by the Asian Development Bank in English under the title [title] (c) [Year of publication] Asian Development Bank. All rights reserved. The quality of this translation and its coherence with the original text is the sole responsibility of the [translator]. The English original of this work is the only official version.

Adaptations-Any adaptations you create should carry the following disclaimer:

This is an adaptation of an original Work (c) Asian Development Bank [Year]. The views expressed here are those of the authors and do not necessarily reflect the views and policies of ADB or its Board of Governors or the governments they represent. $A D B$ does not endorse this work or guarantee the accuracy of the data included in this publication and accepts no responsibility for any consequence of their use.

Please contact publications@adb.org if you have questions or comments with respect to content, or if you wish to obtain copyright permission for your intended use that does not fall within these terms, or for permission to use the ADB logo.

Notes:

1. In this publication, "\$” refers to US dollars.

2. Corrigenda to ADB publications may be found at: http://www.adb.org/publications/corrigenda 


\section{CONTENTS}

TABLES AND FIGURES $\quad$ iv

ABSTRACT $v$

$\begin{array}{ll}\text { I. INTRODUCTION } & 1\end{array}$

II. LITERATURE REVIEW 2

III. ECONOMETRICMODEL

IV. DATA AND EMPIRICAL RESULTS 10

A. Impact of a Shock to the People's Republic of China Activity on Commodity Prices

B. Impact of a Shock to Exchange Rate and Interest Rate on Commodity Prices

C. Asymmetric Impact of a Shock to Commodity Prices on Economic Growth

$\begin{array}{lll}\text { V. CONCLUSION } & 18\end{array}$

$\begin{array}{ll}\text { APPENDIX } & 21\end{array}$

$\begin{array}{ll}\text { REFERENCES } & 25\end{array}$ 


\section{TABLES AND FIGURES}

\section{TABLES}

$1 \quad$ Unit Root Tests with Flexible Fourier 11

2 Model Selection 12

3 Impulse Response Function of a Shock to the PRC's Industrial Production 13

$4 \quad$ Impulse Response Function of a Shock to Exchange Rate 14

$5 \quad$ Impulse Response Function of a Shock to Interest Rate 14

6 Results of the Asymmetric Test of Shocks 16

$7 \quad$ Impulse Responses of the Asymmetric Model 17

$8 \quad$ Impulse Responses of the Symmetric Model 18

A.1 PRC's Share of Selected Global Commodities, 2000-2014 21

A.2 Selected Developing Asian Economies and Their Main Primary Exports, 2013

A.3 Structural Break Tests 21

A.4 Probability Values for Testing the Null of Symmetry 22

\section{FIGURES}

Commodity Prices Approximated by Flexible Fourier Form 12

Appendix Figure: Commodity Prices Demarcating Structural Breaks 23 


\begin{abstract}
The recent slowdown of the People's Republic of China (PRC) has led to question to what extent the PRC demand of commodities can have an impact on commodity prices. We take into account the fact that commodity prices are characterized by structural breaks, and to this end we make use of novel econometric procedures incorporating the Flexible Fourier Form when testing for causal relations between the PRC slowdown and commodity prices. We find varying degrees of response of the PRC slowdown on different commodity prices. Further, this study determines whether the economic growth in selected developing and emerging Asian countries that are heavily dependent on commodities respond in an asymmetric manner to positive commodity price shocks as opposed to negative price shocks. Adopting a structural dynamic regression and censoring positive and negative shocks, we find limited evidence of any asymmetric response of economic activity to positive and negative commodity price shocks.
\end{abstract}

Keywords: commodity prices, economic growth, Flexible Fourier Form, impulse response analysis, PRC slowdown

JEL codes: C22, C32, F43, O47, Q31 


\section{INTRODUCTION}

The People's Republic of China (PRC) has become a major participant in commodity markets, and her resource-intensive growth path followed by a slowdown has led to question to what extent the PRC demand of commodities can be a driver of a change in trend in commodity prices. Commodity prices have shown significant volatility over the years. For example, from 2000 to 2006 both metal and energy commodity prices in general, exhibited an upward drift with frequent fluctuation around this upward trend. Commodity prices then peaked and fell sharply during the period of the recession and were largely driven by energy prices such as of oil and natural gas. Thereafter, the prices started to recover and from 2011, most commodities started to show some signs of stabilization. However, more recently, since 2014 commodity prices have experienced a sustained drop noticeably in energy prices. While, the economic growth of the PRC has averaged around 10\% since 2000, in recent years the growth has fallen to around $7 \%$ and uncertainty around this growth has increased. This has been argued as one of the reasons for the recent drop in commodity prices. The fact that commodity prices are known to be highly volatile and exhibit changing persistence over time may have negative effects on other developing economies heavily dependent on commodities and the PRC for their exports.

In the last decade, the PRC industrial "deepening" with a shift to more capital-intensive sectors has caused a surge in demand for materials, metals, and energy. The PRC's huge appetite for commodities is reflected in Appendix Table A.1. The PRC's rapidly growing commodity intensity since 2000 is likely to be a reflection of the rapid expansion in the tradable export sector and large scale fixed asset investment. These activities are commodity intensive and as a result, the PRC has started to play a dominant role in energy and base metals and has made an impact on global commodity markets as its share of world consumption of commodities remains high. The rapid increase in the demand for commodities, particularly base metals and nonrenewable energy in the PRC has had an impact on commodity prices, and the levels of persistence are expected to last longer than expected. The subsequent decline in commodity prices has also largely been attributed to the PRC slowdown.

Only a fraction of the huge demand for energy and metal commodities by the PRC can only be met by domestic production, hence the PRC depends on commodity imports from natural resource exporters to a large extent. Thus, its role in international commodity trade is also significant and changes in activity levels in the PRC will have implications for its trade partners. The PRC will play an important role in world commodity trade as long as it affects the relative distribution of supply and demand of different commodities across countries (Roache 2012). Accordingly, a fall in demand for commodities due to lower investment would potentially affect commodity exporters to the PRC directly through reduced trade, and all exporters indirectly through commodity price effects. Both these effects can impact the gross domestic product (GDP) growth of these economies based on the extent to which their economy depends on trade in commodities.

The major exporters of energy and metal commodities in Asia are Brunei Darussalam, Azerbaijan, Kazakhstan, Mongolia, Malaysia, and Indonesia, with large direct trade links with the PRC as seen in Appendix Table A.2. These economies are particularly vulnerable to changes in demand for their commodity exports and may be indirectly affected by changes in commodity prices as well. It has often been discussed that external shocks, such as large fluctuations in commodity prices are potential reasons for the low and unstable growth in low-income countries. Developing countries have responded poorly to commodity price shocks and this has led to problems with increasing burdens of debt, currency instability, and low income. Since commodity prices are volatile, it has been argued that countries dependent on commodities for their main source of income have not been able to gain from positive shocks while they have been unable to insulate themselves from negative shocks. For example, 
in many of these economies, public expenditure for infrastructure and development increased when commodity prices experienced a boom and when the prices slumped, such expenditure either had to be abandoned or financed with foreign borrowing. Since the expenditure for such irreversible investment projects depends on the price of commodities, an unexpected increase or decrease in commodity prices causes uncertainty that may amplify the effects of price decreases than increases. This may lead to an asymmetric response in economic growth (Kilian 2014). Thus, commodity prices can have a significant impact on economic growth in commodity-dependent countries and one may expect the response to a positive shock in commodity prices to be different from a negative price shock.

The PRC's rapid economic growth over the last 2 decades has been one of the main drivers of the increased demand in energy and metal commodities. Since the PRC's investment-led growth has been highly commodity intensive, this increased demand for energy and metal commodities over the last decade has been attributed as one of the main reasons for the steady rise in commodity prices. While commentators have alluded that the PRC's increasing investment-led growth matters in relation to the dynamics of international commodity prices, surprisingly, only a handful of studies have been made to quantify the impact of the PRC's economic activity on world commodity prices.

This paper aims to analyze the subject of a PRC slowdown on commodity prices and separately, to analyze whether the response of commodity-dependent developing Asian economies that are reliant on the PRC for their exports respond asymmetrically to commodity price shocks. The analysis is carried out in two parts. The next section provides a literature review, followed by a section describing the econometric methods used. The following sections describe the data and the empirical analysis. The final section provides policy conclusions.

\section{LITERATURE REVIEW}

Focusing on oil prices Elekdag et al. (2007) examine the increase in demand for oil from emerging Asia. They use the Bank of Canada's Global Economy Model (BoC-GEM) which is a Dynamic Stochastic General Equilibrium (DSGE) model to simulate the effect of an increase in East Asian productivity growth on energy intensity of oil usage. They find that an exogenous shock to the PRC's oil demand could lead to an increase in oil prices by about $20 \%$ on impact and a subsequent rise by as much as $60 \%$.

Cheung and Morin (2007) use a regression-based approach including oil prices that are modeled to be dependent on lagged prices of oil, world output gap and the United States (US) real exchange rate. The regression-based approach was employed to estimate the impact of emerging Asia on oil and metal prices. They detect a structural break at the time of the 1997 Asian crisis employing the procedure of Bai and Perron (1998). In general, the findings show that oil and metal prices are becoming increasingly aligned with emerging Asia's economic activity. They find that a $1 \%$ increase in Emerging Asian industrial production leads to a 5.8\% increase in real oil prices. For metals, they are unable to produce indicative figures (due to the lack of cointegration), but find industrial activity in emerging Asia has been more important in driving world metals demand since 1997 and accounting for rising metal intensities in emerging Asia, appears to explain the strength in metal prices to the end of 2005.

Adopting a similar econometric framework Arbatli and Vasishtha (2012) use a reduced form regression model to analyze the extent by which movements in the real prices of oil and metals can be 
The Impact of a People's Republic of China Slowdown on Commodity Prices and Detecting the Asymmetric Responses of Economic Activity in Asian Countries to Commodity Price Shocks

explained by global shocks to the demand for commodities. They assess the role of economic growth worldwide, particularly in countries such as the PRC and India, on the commodity price boom of 2003-2008. In their study, they emphasize that since commodities are storable, the spot prices reflect not only current demand and supply conditions but also expectations of these conditions in the future. Hence, to the extent that inventories link spot and expected future prices, it implies that growth surprises and changing expectations of future conditions should be relevant for the determination of prices than the actual rate of growth. Comparing the importance of different countries, Arbatli and Vasishtha (2012) find that forecast surprises in the US and emerging Asia (i.e., the PRC and India) are important for explaining movements in prices for most commodities in their sample. Furthermore, they find that the real effective exchange rate of the US dollar and interest rates have played a very significant role in explaining industrial commodity prices, both being negatively related with prices. In contrast with some of the previous studies that use forecast revisions to capture demand shocks, they find that growth in emerging Asian countries does not go very far in explaining oil prices-a one percentage point revision in growth in emerging Asia is associated with a $5.5 \%$ increase in copper price, $3.6 \%$ increase in aluminium price, and $3 \%$ increase in zinc price.

A recent study by Roache (2012) makes use of a vector autoregression (VAR) model and applies Granger causality tests and impulse response functions on monthly data to analyze the effect of the PRC's economic activity (as well as the US) on global commodity markets. The results of the study show that shocks to economic activity in the PRC have a small impact on the price of oil and some base metals. For example, a 1 percentage point shock to the PRC's economic activity leads to a cumulative price response of $2 \%$ for oil after 4 quarters and a little over $2 \%$ for copper over the same time horizon. The effect on other commodities is found to be insignificant. Interest rates are found to have a small, negative, and short-lived effect on oil and aluminium prices, consistent with short-term inventory dynamics. In contrast, there is a significant cumulative positive impact on the prices of zinc and tin. A real appreciation of the US dollar has a large, negative, and persistent effect on the prices for most commodities. Shocks to apparent consumption, defined as production minus net exports have no effect on commodity prices. While the PRC's impact on world commodity markets is found to be rising, it remains smaller than that of the US as the dynamics of economic growth shocks in the US which tend to be more persistent, have larger effects on commodity prices.

In a more recent paper, Roache and Roussett (2015) build on the paper by Roache allowing for credit shocks to be included in the VAR model. They find that a 1 percentage point shock in industrial production growth leads to a cumulative response in aluminium prices of $6.39 \%$ after 4 quarters, and for copper, $7.02 \%$; for tin, $6.73 \%$; and for zinc, $2.34 \%$. The response of oil price is $8.81 \%$. These responses are found to be statistically significant and considerably higher compared to those by Roache (2012).

In a very recent study, Klotz, Lin, and Hsu (2014) examine the causal linkages and short-run dynamics between commodity prices, comprising of agricultural, energy, metals, the real interest rate, and economic activity in the PRC over the period 1998-2012. Results of this study provide significant evidence for a causal relationship between the PRC's economic activity and global energy as well as industrial metals prices. The impulse response analysis results show that the impact of a 1 standard deviation shock to economic activity in the PRC has a long-lasting effect on energy prices for 17 months, the effect on industrial metal prices is relatively lower lasting for about 7 months. The results show no significant evidence of any Granger causality relationship from real interest rates to international metal, energy, and agricultural prices. The impulse responses however, show that a shock to interest rates has a significant inverse impact on energy prices. 
Gauvin and Rebillard (2015) employ a global vector autoregressive (GVAR) model to estimate the potential spillovers of a shock to economic activity in the PRC on the rest of the world, mainly concentrating on exporters of metal and energy commodities by making use of a conditional forecast methodology. The argument they put forward in their paper is that if the rebalancing of the PRC's economy (from commodity-intensive investment to private consumption) were to happen through a significant slowdown in growth (in which investment would slow down sharply), then the effect on commodity prices would be significant. They find that a Chinese hard landing (where GDP would drop from the first quarter of 2015 onward, falling rapidly and then stabilizing at 3\%, alongside a deceleration in investment) would cause commodity prices to fall for metals by $66 \%$ and oil prices by $41 \%$ over a 5 year period. This contrasts with the soft landing scenario (where GDP growth will slowly decline by $1 \%$ from 2014 to 2019 alongside investment growth by 5\%) with metal prices relatively declining by a modest $12 \%$ and oil prices by $13 \%$. The exchange rate is found to act as a buffer while the terms of trade worsen. However, the GVAR model that Gauvin and Rebillard (2015) employ is linear, whereas commodity prices are known to show nonlinear behavior. Also there is no evidence to suggest that any rebalancing has been taking place; indeed there is the problem of the unreliability and availability of appropriate data (Cheung and Morin 2007). Of course, Gauvin and Rebillard (2015) state that the Chinese authorities have been unsuccessful so far in rebalancing the economy toward greater private consumption.

Most GVAR studies calculate generalized impulse response functions to shocks that have not been orthogonalized, which makes economic interpretation of the shocks difficult. Further, if structural breaks are present in the data, they cannot be identified and estimated reliably (Pesaran, Smith, and Smith 2007). Commodity prices are known to be nonlinear and this feature has been underlined by Deaton and Laroque (1992) and has been empirically examined in studies by Balagtas and Holt (2009) and Ghoshray and Perera (2016).

Thus, while the GVAR model has advantages in incorporating a large number of variables to be analyzed together, there remain limitations particularly relating to the nonlinearity of commodity prices that arise due to the presence of structural breaks in commodity prices (see Zanias 2005; Kellard and Wohar 2006; Ghoshray 2011; Ghoshray, Kejriwal, and Wohar 2014; Sun and Shi 2015). Taking account of the recent studies in the area, the VAR model approach remains popular. As shown by $\mathrm{Ng}$ and Vogelsang (2002), it is not straightforward to control for breaks even in a VAR since a break in one variable will manifest itself in other variables of the system making it difficult to control for. This would lead to model misspecification and problematic impulse response analysis (Enders and Jones 2016).

Accordingly, we propose to adopt a VAR framework that allows for smooth breaks that increase the power and size properties of the model. Besides economic activity, as an important determinant of commodity demand, we choose the real effective exchange rates. Since global commodity prices are in dollars, a fall in the dollar, would lead to increased demand for commodities, leading to an increase in commodity prices. Another important determinant is interest rates; the relationship with commodity prices is generally perceived to be inverse. For example, an increase in interest rates leads to an increase in storage costs, which leads to a reduction in commodity demand and thereby lowers commodity prices. However, an alternative theory exists which suggests that investment would fall due to an increase in interest rates, leading to a decrease in future supply which would then in turn exert an upward pressure on commodity prices.

There has been a diversity of experience in terms of how commodity-dependent countries have performed over the years. Certain countries have performed better than others and, commodity prices may have been a crucial factor in promoting economic growth. Many countries are dependent 
The Impact of a People's Republic of China Slowdown on Commodity Prices and Detecting the Asymmetric Responses of Economic Activity in Asian Countries to Commodity Price Shocks | 5

on primary commodities as their main source of income, the mix of these commodities varies from country to country and some commodities are important to certain countries than others.

It has been argued that some developing countries have responded poorly to commodity price shocks thus exacerbating debt problems and have experienced very low rates of economic growth. This may have been a result of not being able to reap the gains from positive shocks and being unable to prevent large losses from negative shocks. For example, many governments (whose economies are dependent on primary commodity exports) responded to commodity price booms in the late 1970s by sharply expanding public expenditure for import-intensive public investment programs (Cashin, McDermott, and Pattillo 2004). Subsequently, when commodity prices declined steeply, these programs either had to be abandoned or financed with foreign borrowing. The distinction between commodity price increases and price decreases gains significance because of the fact that the income flow from export receipts that are used for investment projects are irreversible in general and hence an unexpected increase or decrease in commodity prices causes uncertainty that may amplify the effects of price decreases than increases causing an asymmetric response in economic growth (Kilian 2014).

Varangis et al. (2004) stress the importance of distinguishing between positive and negative shocks. They argue that the effect of external shocks on economic growth is asymmetric and the reason that positive shocks do not offset negative ones partly is because negative shocks have irreversible effects. When commodity prices experience a positive shock, this leads to increased foreign exchange earnings which may lead to an excessive appreciation of the real exchange rate. This makes other tradable sectors less competitive in global markets and, ultimately, can lead to a decline in their output, which is known as the Dutch disease. The upshot is that commodity prices can have a significant impact on economic growth in commodity-dependent countries and that one may expect the response to a positive shock in commodity prices to be different from a negative price shock. Deaton and Miller (1996) find in the short run that when commodity prices increase they have a positive impact on economic growth in African countries in comparison to a commodity price decrease. In contrast, Collier and Gunning (1999) find that windfalls from commodity price shocks do not necessarily translate into sustainable increases in income. Evidence for Sub-Saharan Africa (see Dehn 2000) points to possible asymmetry; where price booms are less likely to have a lasting effect on economic growth than price slumps because windfall profits associated with booms tend to be consumed rather than invested; whereas slumps may force farmers to disinvest. In a recent study however, Addison, Ghoshray, and Stamatogiannis (2016) do not find any evidence of asymmetric shocks for Sub-Saharan African countries.

Few studies so far have explicitly focused on the negative spillovers of a growth slowdown in the PRC. Ahuja and Nabar (2012) find that a 1 percentage point slowdown in investment in the PRC is associated with a reduction of global growth of just under one-tenth of a percentage point (the impact being about five times larger than in 2002), with regional supply chain economies (such as Taipei,China; the Republic of Korea; and Malaysia) and commodity exporters with relatively lessdiversified economies being the most vulnerable. For example, in response to a 1 percentage point slowdown in investment growth in the PRC, the estimated effect on Chile's growth (which has a large exposure to the PRC) is a reduction of close to two-fifths of a percentage point; whereas, commodity exporters such as Australia and Brazil with more diversified economies suffer relatively smaller declines in growth.

This study analyzes the asymmetric effect of commodity price shocks on the growth of industrial production of selected commodity-dependent Asian countries. Following the reasoning put forward earlier, we determine whether a positive commodity price shock has a larger effect than a 
negative commodity price shock. This approach has been employed on Sub-Saharan African countries (see, for example, Addison, Ghoshray, and Stamatogiannis 2016) but not on Asian countries that are dependent on commodities. To this end we adopt the procedure put forward by Kilian and Vigfusson (2011) that allows us to separately distinguish the response of economic growth to positive and negative price shocks.

Recent studies on external shocks and their impact on economic activity (such as Broda 2004; Raddatz 2007; Collier and Goderis 2012; Addison, Ghoshray, and Stamatogiannis 2016) have employed a panel VAR or panel error correction model approach. A major drawback of these studies is that the dynamics are common across cross-sectional units. This assumption is driven by the fact that with the limited time series data available, the country-specific dynamics cannot be estimated. However, Pesaran and Smith (1995) state that this assumption will likely result in obtaining estimates that underestimate (overestimate) short-run (long-run) impact of the shocks if the dynamics differ across countries. Juselius, Møller, and Tarp (2014) lend support to the argument that panel models require fairly strict assumptions. While Raddatz (2007) argues that this criticism can be mitigated by choosing countries that are relatively homogenous, we find our results from individual country evidence, confirms the heterogeneity of experience. Besides, the explanatory variables are likely to be heterogeneous. As a case in point, the dynamics of individual commodity prices which may be closely related (such as cocoa and coffee), have been found by recent studies (see Kellard and Wohar 2006, Ghoshray 2011) to exhibit dynamics that are widely different. These studies have recommended against using aggregate indices that constitute a group of commodities (such as metals, beverages, etc.) and have concluded that individual commodities should be modeled separately.

\section{ECONOMETRIC MODEL}

As described in the previous section, commodity prices have been characterized by broken trends and structural breaks and as such, the relationship between macroeconomic variables in a system that includes commodity prices is not straightforward. Addressing this problem Enders and Jones (2016) build on the VAR model by allowing for the Flexible Fourier Form to capture the multiple smooth shifts in the data that are likely to be present in the VAR model.

The literature on structural beaks identifies that two types of breaks may be present in the data; additive outliers (where the structural break is in the deterministic portion of the model) and innovational outliers (where the structural break is in the stochastic portion of the model), which makes the detection of a structural mean shift in the innovational model more difficult (see $\mathrm{Ng}$ and Vogelsang 2002). The consequences of ignoring the innovational and additive outliers in a VAR model have been clearly elucidated in Ng and Vogelsang (2002).

From an econometric methodological point of view, the key question is how to control for the number of breaks when the number of breaks and the form of such breaks are unknown. Enders and Lee (2012) employ a variant of the Flexible Fourier Form due to Gallant (1981) to control for structural breaks in a VAR. They consider a VAR where the deterministic part $\left(d_{t}\right)$ of the equation for the variable $\left(y_{t}\right)$ to be included in the VAR is given by:

$$
d_{i t}=\delta_{i 0}+\delta_{i 1} d_{1 t}+\delta_{i 2} d_{2 t}+\cdots+\delta_{i m} d_{m t}
$$


where the $d_{i t}$ represents potentially smooth functions over time, the parameters $\delta_{i j}(j=1,2, \ldots, m)$ indicated the magnitude of the effect of break $j$ on variable $i$; and $m$ denotes the number of breaks in variable $i$.

If the breaks are sharp, then one could employ Heaviside Indicator Functions such that $\delta_{j t}=1$, if $t>t_{j}$ and $\delta_{j t}=0$ otherwise. However, if the number of breaks is large and they tend to be smooth, then an alternative methodology is necessary that allows $\delta_{j t}$ to be a smooth function over time. To this end, Enders and Jones (2016) use a simplified version of the Flexible Fourier Form to represent the deterministic portion $\left(d_{t}\right)$ of the variable $\left(y_{t}\right)$ to be given by:

$$
d_{i t}=a_{i 0}+\sum_{k=1}^{n} a_{i k} \sin (2 \pi k t / T)+\sum_{k=1}^{n} a_{i k} \cos (2 \pi k t / T)
$$

This formulation is particularly useful as a small number of low-frequency components from a Fourier approximation can capture the essential characteristics of a series containing structural breaks. This has been demonstrated in the recent studies put forward by Astill et al. (2015) and Rodrigues and Taylor (2012), among others. The key issue here is that the Flexible Fourier can mimic the nature of the breaks by being completely agnostic of the size, location, and number of the break dates. In a sense, the issue of controlling for the breaks is transformed into the choice of the appropriate frequencies to include into the model. As stated by Enders and Jones (2016), we set the frequency of the trigonometric components to be $n \leq 3$.

As a prelude to testing the VAR with Flexible Fourier, it is reasonable to test for stationarity of the data series included in the VAR model. To this end, Enders and Lee (2012) have put forward an appropriate Lagrange Multiplier (LM)-based unit root test that includes trigonometric components. This is carried out using the following steps:

First, estimate the following regression:

$$
\Delta y_{t}=a_{0}+\sum_{k=1}^{n} a_{k} \sin (2 \pi k t / T)+\sum_{k=1}^{n} b_{k} \cos (2 \pi k t / T)+v_{t}
$$

Next, using the estimates from the above equation, the detrended series $\tilde{S}_{t}$ is constructed by estimating the following regression;

$$
\tilde{S}_{t}=y_{t}-\hat{a}_{0} t-\sum_{k=1}^{n} \hat{a}_{k} \sin (2 \pi k t / T)+\sum_{k=1}^{n} \hat{b}_{k} \cos (2 \pi k t / T)
$$

Finally, the unit root test is carried out by estimating the following regression:

$$
\Delta y_{t}=\phi \tilde{S}_{t}+d_{0}+\sum_{k=1}^{n} d_{1 i} \Delta \sin (2 \pi k t / T)+\sum_{k=1}^{n} d_{2 i} \Delta \cos (2 \pi k t / T)+\varepsilon_{t}
$$

A completely agnostic approach to the problem of detecting breaks is to select $k$ using purely statistical means. We use a grid-search method such that the value $k=\hat{k}$ minimizes the sum of squared residuals from (5). Specifically, for each integer value of $k$ in the interval $1 \leq k \leq k_{\max }$ we estimate (5) and select $k$ from the regression yielding the best fit. We suggest using the integer values 1 through 5 since low frequencies are associated with breaks. As established in Becker, Enders, and Hurn (2004), the presence of high-frequency components could be due to various forms of stochastic parameter instability. 
The null hypothesis of interest is $H_{0}:(\phi=0)$. If the null is rejected, we can conclude that the data series is stationary. In the case of serially correlated errors, the equation is augmented by adding lagged values of $\Delta \tilde{S}_{t}$.

The choice of variables in this study is stacked in a vector $\mathbf{z}_{t}^{\prime}=\left[I P C H_{t}, R E E R_{t}, I R_{t}, P C O M_{t},\right]$ where $I P C H_{t}$ denotes the industrial production growth of the PRC, $P C O M_{t}$ is the price of the primary commodity, $R E E R_{t}$ is the real exchange rate, and $I R_{t}$ is the interest rate. The lag length $l$ was chosen according to the Akaike Information Criterion (AIC). The linear VAR would take the following form:

$$
\mathbf{z}_{t}=\mathbf{A}_{0}+\sum_{i=1}^{l} \mathbf{A}_{i} \mathbf{z}_{t-i}+\mathbf{e}_{t}
$$

where $\mathbf{A}_{0}$ is a $5 \times 1$ vector of intercepts, $\mathbf{A}_{i}$ is a $5 \times 5$ coefficient matrix, while $\mathbf{e}_{t}$ is a $5 \times 1$ vector of error terms. The error vector is ordered with industrial production growth of the PRC causally prior to exchange rates, interest rates, and commodity prices, which is similar to the study by Roache (2012).

In the case of the Flexible Fourier Form, the VAR model is estimated as:

$$
\begin{gathered}
\mathbf{z}_{t}=\mathbf{A}_{0}(t)+\sum_{i=1}^{l} \mathbf{A}_{i} \mathbf{z}_{t-i}+\mathbf{e}_{t} \\
\mathbf{A}_{0}(t)=\left[\delta_{1}(t), \delta_{2}(t), \delta_{3}(t), \delta_{4}(t), \delta_{5}(t)\right]^{\prime}
\end{gathered}
$$

and each intercept $\delta_{i}(t)$ depends on the $n$ Fourier frequencies such that:

$$
\delta_{i}(t)=a_{i}+b_{i} t+\sum_{k=1}^{n} a_{i k} \sin (2 \pi k t / T)+\sum_{k=1}^{n} a_{i k} \cos (2 \pi k t / T)
$$

The VAR model with Fourier frequencies is estimated beginning with a trigonometric frequency set equal to 3 . This model has good size and power properties when testing for smooth structural change in a VAR. Ignored structural breaks in a VAR result in a misspecified model. We carry out a model selection test using the $\mathrm{AIC}$ to determine model performance.

In the second part of the study, to analyze the effects of commodity price shocks on economic activity in developing Asian countries, we make use of a structural dynamic model that allows for asymmetric responses to be detected.

The two variables denoted by $y_{t}$ and $x_{t}$, are the variables of interest, being industrial production growth and commodity prices respectively.

In the following dynamic model, we have a symmetric data generating process in which the responses of $y_{t}$ to positive and negative values of $x_{t}$ are the same.

$$
\begin{aligned}
& \Delta x_{t}=b_{10}+\sum_{i=1}^{p} b_{11, i} \Delta x_{t-i}+\sum_{i=1}^{p} b_{12, i} \Delta y_{t-i}+\varepsilon_{1, t} \\
& \Delta y_{t}=b_{20}+\sum_{i=0}^{p} b_{21, i} \Delta x_{t-i}+\sum_{i=1}^{p} b_{22, i} \Delta y_{t-i}+\varepsilon_{2, t}
\end{aligned}
$$


where $\Delta y_{t}$ and $\Delta x_{t}$ denote the differenced log variables thereby interpreting the variables as economic growth and commodity price changes, respectively. The error terms $\varepsilon_{1, t}$ and $\varepsilon_{2, t}$, are white noise processes, determined by the appropriate lag length selection of the VAR chosen according to the Schwartz Information Criterion (SIC).

However, if we wish to estimate a censored structural dynamic regression model, so that we allow for only positive values of $x_{t}$ (denoted by $x_{t}^{+}$) in the second equation of (1); then as the datagenerating process may be symmetric, neglecting the negative values of $x_{t}$ would make the regression invalid and the effects of positive values of $x_{t}$ (denoted by $x_{t}^{+}$) on $y_{t}$ will be overestimated (see Kilian and Vigfusson 2011).

The structural nonlinear dynamic model proposed by Kilian and Vigfusson (2011) can produce consistent estimators of coefficients regardless of whether the data-generating process is symmetric or asymmetric. The model allows both positive and negative price shocks to affect the economy (but to different magnitudes). We make use of a measure of price shocks, in which price increases and decreases are treated separately in the regression.

The asymmetric model due to Kilian and Vigfusson (2011) is to employ a transformation of commodity price as given by the nonlinear dynamic model below:

$$
\begin{gathered}
\Delta x_{t}=b_{10}+\sum_{i=1}^{p} b_{11, i} \Delta x_{t-i}+\sum_{i=1}^{p} b_{12, i} \Delta y_{t-i}+\varepsilon_{1, t} \\
\Delta y_{t}=b_{20}+\sum_{i=0}^{p} b_{21, i} \Delta x_{t-i}+\sum_{i=1}^{p} b_{22, i} \Delta y_{t-i}+\sum_{i=0}^{p} g_{21, i} \Delta x_{t-i}^{+}+\varepsilon_{2, t}
\end{gathered}
$$

Following the line of reasoning proposed by Mork (1989), we adopt a nonlinear model of commodity prices where the following auxiliary variable is constructed:

$$
\Delta x_{t}^{+}=\max \left[0, \Delta x_{t}\right]
$$

In this case, the model allows us to separate commodity price increases from commodity price decreases, therefore allowing a test for symmetry of prices on economic growth. The first equation of (2) is identical to the first equation of (1); but the second equation in (2) includes $x_{t}$ and $x_{t}^{+}$and as such, allows for commodity price increases to marginally affect economic growth differently from price decreases.

The key advantage of equation (2) or (3) is that the dynamic responses are consistently estimated being completely agnostic to the nature of the data-generating process (Kilian and Vigfusson 2009). If commodity price increases and decreases received exactly the same weight in regressions of per capita economic growth, it would imply that the dynamic responses of per capita income growth to such commodity price shocks are symmetric. Following the traditional approach of testing for asymmetry to positive and negative shocks due to Mork (1989), we can test for symmetry in the framework of (2) by the following hypothesis:

$$
H_{0}:\left(g_{21,1}=g_{21,2}=\cdots g_{21, p}=0\right)
$$


The hypothesis test given by (3) can be conducted by means of a Wald test with an asymptotic chi-squared distribution. Kilian and Vigfusson (2011) note that the test due to Mork (1989) excludes the contemporaneous regressor and put forward a modified version of the model by Mork (1989), which involves testing the following null hypothesis:

$$
H_{0}:\left(g_{21,0}=g_{21,1}=g_{21,2}=\cdots g_{21, p}=0\right)
$$

Kilian and Vigfusson (2011) note that the modified version of Mork's model may have higher power and we choose to employ this test in our subsequent analysis.

To understand why all these factors matter, consider feeding equation (10) with a very large positive shock. For a given commodity price variable $x_{t}$, it is very likely that $\Delta x_{t}$ will be positive and that $x_{T}^{+}$will be different from zero, affecting economic growth through the coefficient $g_{21,0}$. Alternatively, the smaller the size of the shock, the higher the probability that the term $x_{T}^{+}$will be zero, resulting in a more muted response of $y_{t}$.

We compute the impulse responses as documented by Kilian and Vigfusson (2011). We first estimate the unrestricted structural dynamic model as given by (10) and calculate the unconditional impulse responses to both positive and negative shocks. We then construct a Wald test where the null hypothesis is of symmetric responses to positive and negative shocks. Choosing a time horizon $H$, the null hypothesis is set up as:

$$
I_{y}^{h}(\delta)+I_{y}^{h}(-\delta)=0 \text { for } h=0,1,2, \ldots, H
$$

The Wald test has an asymptotic $\chi_{H+1}^{2}$ distribution assuming that the parameter estimates in (10) are asymptotic normal. The magnitude of the shock is given by $\delta$. To carry out this test, an estimate of the variance of $I_{y}^{h}(\delta)+I_{y}^{h}(-\delta)=0$ is required, which is obtained using a bootstrap simulation (see Kilian and Vigfusson 2011 for details).

\section{DATA AND EMPIRICAL RESULTS}

For the first part of the analysis, the data consists of growth of industrial production of the PRC from CEIC Data Company; commodity prices which include, aluminium, copper, iron, gas, coal, oil, tin, and zinc collected from the IMF International Financial Statistics via Haver Analytics; Real Effective Exchange Rate Index: Based on Consumer Price Index, 2010 = 100 from the CEIC Data Company; and the US Federal Funds interest rate and the US consumer price index sourced from the Haver Analytics and Federal Reserve Bank of St. Louis. The frequency of the data is monthly, and the span of the data is from January 2000 to June 2015.

For the second part, the data includes industrial production of, Azerbaijan, Kazakhstan, Indonesia, Malaysia, and Mongolia. The countries are selected on the basis that these countries are dependent on commodities as a major source of income and primarily export to the PRC (see Appendix Table A.2 for details). The data is seasonally adjusted and the source is the CEIC Data Company. Commodity price data is as described above.

Before estimating the VAR with Flexible Fourier, it is reasonable to test for stationarity of the data series included in the VAR model. Further, we have also emphasized the importance of structural 
breaks in commodity prices (see Appendix Table A.3). Accordingly, we conduct the unit root tests that allow for Flexible Fourier Form. To this end, Enders and Lee (2012) have put forward an appropriate LM-based unit root test that includes trigonometric components. The results are contained in Table 1.

\section{Table 1: Unit Root Tests with Flexible Fourier}

\begin{tabular}{lllr}
\hline Commodity & $\boldsymbol{k}$ & $\mathbf{L} \boldsymbol{M}_{\boldsymbol{\tau}}$ & Lag \\
\hline Aluminium & 3 & $-5.43^{*}$ & 4 \\
Coal & 1 & $-5.03^{*}$ & 11 \\
Copper & 3 & $-4.90^{*}$ & 11 \\
Iron & 3 & $-4.77^{*}$ & 1 \\
Gas & 3 & $-5.26^{*}$ & 11 \\
Nickel & 1 & -2.74 & 1 \\
Oil & 2 & $-5.72^{*}$ & 11 \\
Tin & 1 & $-3.95^{*}$ & 11 \\
Zinc & 3 & $-4.05^{*}$ & 10 \\
\hline Macroeconomic variables & & & 7 \\
\hline Real exchange rate & 2 & $-3.61^{*}$ & 10 \\
Interest rate & 3 & $-6.24^{*}$ & \\
\hline
\end{tabular}

Notes: ${ }^{*}$ denotes significance at the $10 \%$ level. Lag length selected according to the general to specific methodology. $k$ denotes the frequency.

Source: Authors' estimates.

As described by Enders and Lee (2012), we follow the grid-search method such that the value $k=\hat{k}$ minimizes the sum of squared residuals from (5). This is listed in the first column of results in Table 1. The lag length given in the last column is chosen according to the general to specific methodology as suggested by Enders and Lee (2012). The LM test statistic with respect to the null hypothesis of interest, that is, $H_{0}:(\phi=0)$ is contained in the middle column of results in Table 1 . The results of the test statistics show that we can reject the null hypothesis for all variables except the commodity nickel. This implies that for all the variables included in the study we find that apart from the commodity nickel, we can conclude that the variables are stationary. This result is not surprising, as we know that the power of a unit root test is low in the presence of structural breaks in the economic time series (Perron 1989).

It is well known that commodity prices are characterized by structural breaks. An extant literature exists that have found commodity prices to be plagued by structural breaks. Some of the studies include Zivot and Andrews (1992); Zanias (2005); Kellard and Wohar (2006); Harvey, Leybourne, and Taylor (2010); Ghoshray (2011); Ghoshray, Kejriwal, and Wohar (2014); Sun and Shi (2015). We test for structural break in commodity prices used in this study and find that all commodity prices are found to contain two structural breaks. The results of the structural break test due to Bai and Perron (2003) and graphs demarcating the structural break points and corresponding regimes that demarcate the breaks are contained in Appendix Table A.3 and the appendix figure.

The key point is that the Flexible Fourier Form can mimic the nature of the breaks, by being agnostic of the number of breaks, the break dates, and the size of the breaks. Rather than controlling for the breaks, we choose the appropriate frequencies in the model and Enders and Jones (2016) show that it is possible to mimic the breaks with a small number of low-frequency trigonometric components. The approximations of possible break dates are shown in the data of commodity prices in the figure below. 


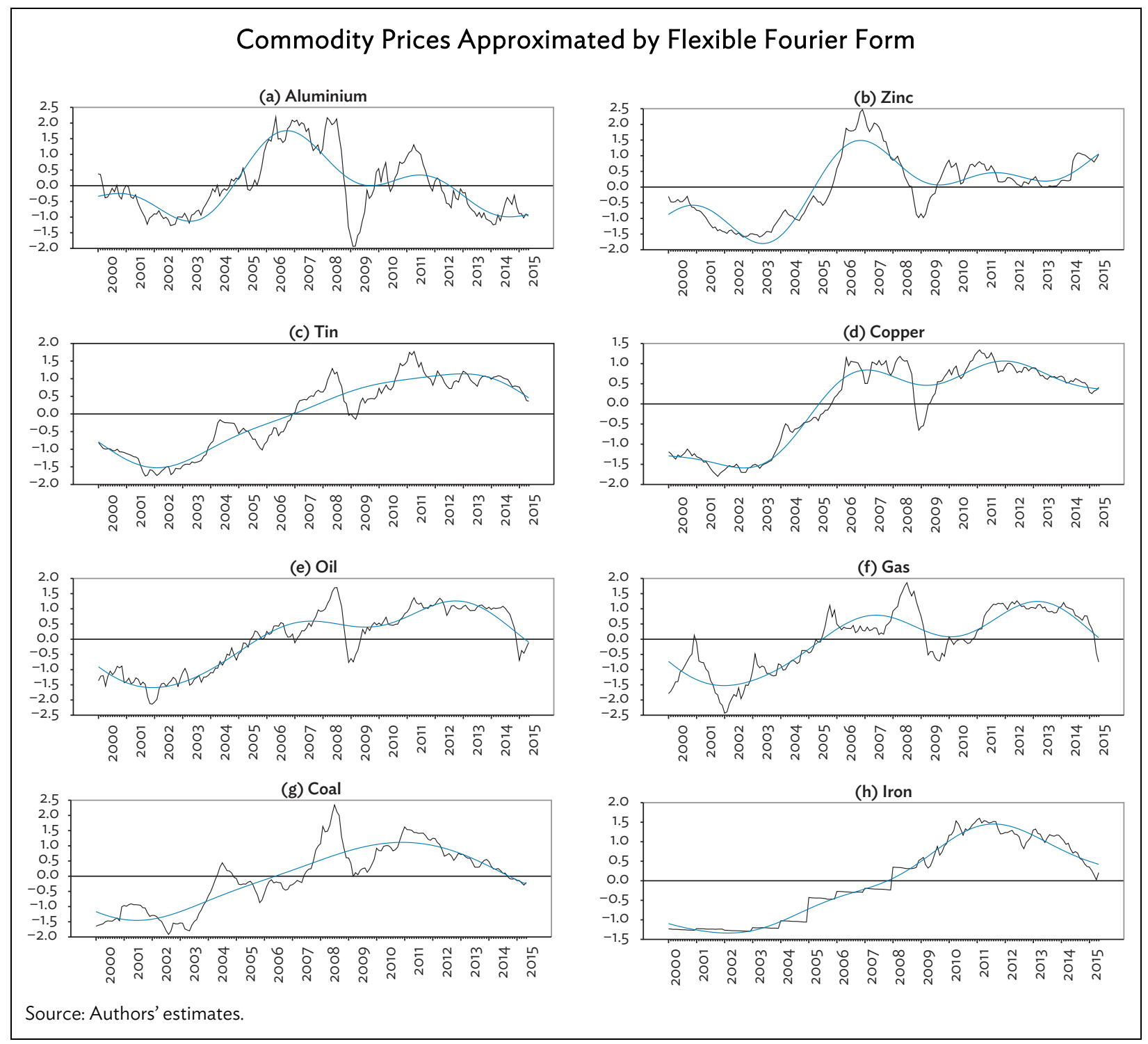

Prior to conducting an analysis using a VAR with Flexible Fourier Form, we check how this type of VAR model compares with the linear VAR model. Using a model selection criterion (AIC) we find that for all the cases, the Flexible Fourier Form VAR model outperforms the linear VAR, which motivates this methodology. The results of this model selection criterion are given in Table 2 .

Table 2: Model Selection

\begin{tabular}{lcc}
\hline & Linear & Flexible Fourier Form \\
\hline Aluminium & $-1,312.7$ & $-1,414.5$ \\
Coal & $-1,211.2$ & $-1,296.4$ \\
Copper & $-1,214.4$ & $-1,298.7$ \\
Iron & $-1,020.5$ & $-1,116.1$ \\
Gas & $-1,201.3$ & $-1,286.1$ \\
Oil & $-1,085.6$ & $-1,176.1$ \\
Tin & $-1,230.1$ & $-1,299.4$ \\
Zinc & $-1,281.3$ & $-1,371.4$ \\
\hline
\end{tabular}

Source: Authors' estimates. 


\section{A. Impact of a Shock to the People's Republic of China Activity on Commodity Prices}

Table 3 lists the cumulative response of a shock to real activity in the PRC and its effects on commodity prices. The effect of a 1 percentage point decline in growth rate of industrial production has a significant effect on the prices of most metals. For copper, we find that the initial impact of the shock in the first quarter lowers price by $4.2 \%$. By the second quarter, the accumulated response of the shock depresses copper prices to about $7 \%$. Following into the third and fourth quarters, while the effect of the shock lowers prices even further, the responses are no longer significant. A higher effect is found for other metals such as aluminium and tin. In the first three quarters, we find that the responses to a shock to real activity in the PRC is significant, lowering prices cumulatively by $11.9 \%$ and $20.8 \%$ for aluminium and tin, respectively. After the third quarter, the responses become insignificant. In the case of iron, the magnitude of the responses is much smaller from the first quarter to the third quarters, bringing prices down by $4.5 \%$ cumulatively. Whereas in the case of zinc, the response is small and significant in magnitude in the first quarter, and becomes insignificant in the subsequent quarters.

In the case of energy commodities, we find that a relatively higher response is obtained for coal where following a 1 percentage point decrease in industrial production growth, prices drop cumulatively to $11.5 \%$ in three quarters. For oil and natural gas, the responses are smaller-7\% for oil and $4.4 \%$ for gas over three quarters. The cumulative response in the fourth quarter for oil, natural gas and coal become insignificant.

The sustained decline in commodity prices due to a negative shock in real activity in the PRC is not surprising as we would expect the shocks to be persistent given the nature of commodity prices. While accounting for Flexible Fourier Form, we find that the prices are stationary which follows economic theory (Deaton and Laroque 2003, Wang and Tomek 2007; however, in empirical studies, it is widely accepted that commodity prices tend to be highly persistent. As a result, a shock in commodity prices is expected to dissipate; however, the rate of decline is expected to be slow. In the case of copper, oil, and zinc the magnitude of these results are somewhat similar to Roache and Roussett (2015).

The large declines that are produced from the impulse response function analysis, particularly for metals seem to reflect the recent price declines that have been seen since the slowdown of the PRC's economy. Our results suggest the steep decline in commodity prices as a result of the slowdown in the PRC, is likely to continue in the first three quarters after the shock, but the effect of the shock is expected to dissipate over time.

Table 3: Impulse Response Function of a Shock to the PRC's Industrial Production

\begin{tabular}{lclllllll}
\hline Horizon & Aluminium & Copper & Iron & Zinc & Tin & Oil & Gas & Coal \\
\hline First quarter & $-5.969^{*}$ & $-4.200^{*}$ & $-2.546^{*}$ & $-2.563^{*}$ & $-9.379^{*}$ & $-3.270^{*}$ & -1.942 & -4.152 \\
Second quarter & $-9.962^{*}$ & $-6.985^{*}$ & $-3.885^{*}$ & -4.115 & $-16.710^{*}$ & $-5.980^{*}$ & $-3.490^{*}$ & $-8.429^{*}$ \\
Third quarter & $-11.860^{*}$ & -7.441 & $-4.461^{*}$ & -3.271 & $-20.780^{*}$ & $-7.004^{*}$ & $-4.390^{*}$ & $-11.450^{*}$ \\
Fourth quarter & -12.377 & -6.685 & -4.586 & -1.542 & -22.141 & -6.909 & -4.675 & -12.841 \\
\hline
\end{tabular}

PRC = People's Republic of China.

Note: ${ }^{*}$ denotes significance at the $10 \%$ level.

Source: Authors' estimates. 


\section{B. Impact of a Shock to Exchange Rate and Interest Rate on Commodity Prices}

Tables 4 and 5 show the effect of monetary policy related variables, being US dollar real exchange rate, and the average monthly Federal Funds effective interest rate on commodity prices. Various studies including those of Frankel (2008) and Frankel and Rose (2009) have emphasized about the effect of US monetary policy on commodity prices.

The findings in Table 4 show that a one-time 1\% appreciation in the US dollar real exchange rate leads to lower commodity prices in most cases. This is expected, since global commodity prices are priced in dollars, a fall in the dollar, would lead to increased demand for commodities, leading to increase in commodity prices. However, the response of commodity prices to a shock in exchange rates is not always significant over the horizon chosen. For example, for natural gas, we find the responses to be significant for all the quarters, and the effect of the shocks increases significantly in magnitude over the quarters. For coal, the shocks last for three quarters with a cumulated response of $22.53 \%$, while for oil, the shocks last for two quarters with a cumulative response of $7.38 \%$. For all the three energy commodities, the effect of a 1 percentage point increase in the US dollar real exchange rate leads to lower energy prices. In the case of metals, we find that aluminium, copper, and tin prices fall by marginal amounts in the first quarter in response to a real effective exchange rate shock but the effect of the shock dies out for these metals after the second quarter. In the case of iron is a significant response to the shock for the first three quarters. In the case of zinc we obtain a negative response as expected in the first quarter but subsequently obtain a cumulated response in the third and fourth quarters which are contrary to a priori expectations. The results for oil and aluminium are similar to those found by Roache (2012), while the magnitude is relatively smaller for copper and tin.

Table 4: Impulse Response Function of a Shock to Exchange Rate

\begin{tabular}{lcccccccc}
\hline Horizon & Aluminium & Copper & Iron & Zinc & Tin & Oil & Gas & Coal \\
\hline First quarter & $-1.33^{*}$ & $-1.22^{*}$ & $-1.02^{*}$ & $-1.40^{*}$ & $-0.18^{*}$ & $-2.27^{*}$ & $-1.97^{*}$ & $-2.39^{*}$ \\
Second quarter & $-6.00^{*}$ & $-4.59^{*}$ & $-3.89^{*}$ & 0.23 & $-2.38^{*}$ & $-7.38^{*}$ & $-8.33^{*}$ & $-12.34^{*}$ \\
Third quarter & -8.42 & -4.17 & $-6.82^{*}$ & $8.22^{*}$ & -2.48 & -11.14 & $-16.06^{*}$ & $-22.53^{*}$ \\
Fourth quarter & -7.61 & $-0.84^{*}$ & -8.94 & $17.85^{*}$ & -0.33 & -12.55 & $-22.84^{*}$ & -28.64 \\
\hline
\end{tabular}

Note: ${ }^{*}$ denotes significance at the $10 \%$ level.

Source: Authors' estimates.

Table 5: Impulse Response Function of a Shock to Interest Rate

\begin{tabular}{lcccccccc}
\hline Horizon & Aluminium & Coal & Copper & Iron & Gas & Oil & Tin & Zinc \\
\hline First quarter & 0.003 & 0.010 & 0.021 & -0.0003 & $-0.016^{*}$ & 0.051 & $0.021^{*}$ & 0.032 \\
Second quarter & $0.088^{*}$ & $0.136^{*}$ & $0.163^{*}$ & 0.018 & -0.034 & $0.217^{*}$ & $0.169^{*}$ & $0.144^{*}$ \\
Third quarter & $0.205^{*}$ & $0.326^{*}$ & $0.317^{*}$ & 0.053 & -0.020 & $0.402^{*}$ & $0.373^{*}$ & 0.247 \\
Fourth quarter & $0.282^{*}$ & $0.478^{*}$ & 0.391 & 0.094 & -0.024 & $0.562^{*}$ & $0.527^{*}$ & 0.297 \\
\hline
\end{tabular}

Note: ${ }^{*}$ denotes significance at the $10 \%$ level.

Source: Authors' estimates.

Table 5 shows the response of commodity prices to a one-time 100 basis point increase in the average monthly real Federal Funds effective interest rate. While Roache (2012) postulates that we should expect this to lead to lower commodity prices, there have been arguments put forward that the effect of interest rate shocks could be ambiguous. In the case of energy commodities, coal and oil show a delayed response to a shock, while the impact of a shock is felt by gas prices in the first quarter. While 
The Impact of a People's Republic of China Slowdown on Commodity Prices and Detecting the Asymmetric Responses of Economic Activity in Asian Countries to Commodity Price Shocks | 15

the effect of gas is negative, for oil and coal, it is positive. However, the magnitude of the response to the shock is very small. In the case of metals, we find small responses to a shock in interest rates. For aluminium, the response is significant from the second quarter, and for copper, it is the second and third quarters only; whereas for tin, the initial impact of the response is felt in the first quarter and continues until the fourth quarter. For iron, there is no significant response.

The upshot from these results is that in general, the impact and responses of commodity prices to a shock in economic activity in the PRC are mixed. While there seems to be considerable evidence that a shock to the PRC causes a significant response for all commodity prices, the impact on most metals and on coal is higher than on oil and natural gas. The response of commodity prices due to a shock in interest rates is much smaller and in some cases, insignificant at least over selected quarters of the horizon period. The response of commodity prices to a shock in real exchange rates is relatively higher for energy prices in comparison to metal prices, with zinc being an outlier.

The analysis of the PRC economic activity on commodity prices was further evaluated by testing whether commodity prices respond asymmetrically to an increase or a decrease in the PRC's economic growth in a structural nonlinear dynamic model. The results of the analysis (see Appendix Table A.4) show that there is no such evidence.

\section{Asymmetric Impact of a Shock to Commodity Prices on Economic Growth}

Following on from the discussion earlier about the possibility of economic growth in selected Asian countries that are commodity dependent and export a bulk of the commodities to the PRC, to respond asymmetrically to commodity price shock increases and decreases, we employ the impulse response function analysis and compute the 1 and 2 standard deviation exogenous shocks to the structural model given by (2). However, as noted by Kilian and Vigfusson (2011), these models are subject to sampling uncertainty and as a consequence, it is important to proceed to test for symmetry using a hypothesis test. Accordingly, we construct a Wald test where the null hypothesis is of symmetric responses to positive and negative shocks. This test is conducted first to ascertain whether the response of economic growth to positive as opposed to negative commodity price shocks is asymmetric. The results of the test for all the variables (countries and commodity price pairs) considered in this model are tabulated in Table 6 below.

We tabulate the p-values of the test of the null hypothesis $H_{0}: I_{y}^{h}(\delta)=I_{y}^{h}(-\delta)$, which is the test for symmetric responses to a small shock (measured by 1 standard deviation) or a large shock (measured by 2 standard deviations) based on the price increase specification given by (2). We calculate the probability value for asymmetry for all time horizons up to 12 months.

In the analysis that follows, we pair up the price to a country that is heavily dependent on the commodity (given by the export share of the commodity as a percentage of GDP). Accordingly, we obtain 11 possible pairs between commodity prices and the industrial production of commodityexporting countries. Out of the 11 pairs, we find asymmetric responses to commodity price shocks to occur for only three possible pairs and of different variability. For example, Azerbaijan is found to respond asymmetrically to an oil and natural gas price shock. In the case of Azerbaijan, while there is no significant asymmetric response on the impact of a shock in both the cases of oil prices and natural gas prices, the recursive nature of the model gives rise to significant asymmetric responses over the subsequent months which persist for several months. An initial response for a couple of months is also found in the case of Malaysia to a shock in tin prices. 
Table 6: Results of the Asymmetric Test of Shocks

\begin{tabular}{|c|c|c|c|c|c|c|c|c|c|c|c|c|}
\hline \multirow{3}{*}{ Horizon } & \multicolumn{6}{|c|}{ Mongolia } & \multicolumn{6}{|c|}{ Kazakhstan } \\
\hline & \multicolumn{2}{|c|}{ Coal } & \multicolumn{2}{|c|}{ Iron } & \multicolumn{2}{|c|}{ Copper } & \multicolumn{2}{|c|}{ Oil } & \multicolumn{2}{|c|}{ Iron } & \multicolumn{2}{|c|}{ Copper } \\
\hline & 1SD & $2 S D$ & 1SD & $2 S D$ & 1SD & $2 S D$ & 1SD & $2 S D$ & 1SD & $2 S D$ & 1SD & $2 S D$ \\
\hline 0 & 0.483 & 0.493 & 0.667 & 0.673 & 0.119 & 0.129 & 0.485 & 0.499 & 0.129 & 0.142 & 0.057 & 0.060 \\
\hline 1 & 0.661 & 0.684 & 0.852 & 0.852 & 0.295 & 0.314 & 0.686 & 0.707 & 0.240 & 0.259 & 0.124 & 0.135 \\
\hline 2 & 0.819 & 0.883 & 0.954 & 0.954 & 0.486 & 0.509 & 0.858 & 0.874 & 0.347 & 0.378 & 0.230 & 0.257 \\
\hline 3 & 0.914 & 0.915 & 0.985 & 0.985 & 0.640 & 0.661 & 0.928 & 0.941 & 0.487 & 0.525 & 0.365 & 0.399 \\
\hline 4 & 0.965 & 0.965 & 0.996 & 0.996 & 0.769 & 0.787 & 0.970 & 0.977 & 0.616 & 0.651 & 0.501 & 0.540 \\
\hline 5 & 0.986 & 0.987 & 0.999 & 0.999 & 0.860 & 0.872 & 0.989 & 0.992 & 0.647 & 0.681 & 0.587 & 0.614 \\
\hline 6 & 0.995 & 0.995 & 1.000 & 1.000 & 0.916 & 0.923 & 0.996 & 0.997 & 0.754 & 0.781 & 0.678 & 0.723 \\
\hline 7 & 0.996 & 0.994 & 1.000 & 1.000 & 0.954 & 0.959 & 0.998 & 0.999 & 0.814 & 0.831 & 0.773 & 0.811 \\
\hline 8 & 0.997 & 0.995 & 1.000 & 1.000 & 0.970 & 0.978 & 0.999 & 0.999 & 0.856 & 0.872 & 0.841 & 0.870 \\
\hline 9 & 0.999 & 0.997 & 1.000 & 1.000 & 0.984 & 0.985 & 1.000 & 1.000 & 0.906 & 0.919 & 0.862 & 0.855 \\
\hline 10 & 0.999 & 0.999 & 1.000 & 1.000 & 0.985 & 0.990 & 1.000 & 1.000 & 0.942 & 0.951 & 0.905 & 0.901 \\
\hline 11 & 1.000 & 0.999 & 1.000 & 1.000 & 0.982 & 0.988 & 1.000 & 1.000 & 0.965 & 0.971 & 0.922 & 0.934 \\
\hline \multirow[t]{2}{*}{12} & 1.000 & 1.0000 & 1.000 & 1.000 & 0.989 & 0.994 & 1.000 & 1.000 & 0.980 & 0.984 & 0.948 & 0.947 \\
\hline & \multicolumn{6}{|c|}{ Malaysia } & \multicolumn{6}{|c|}{ Indonesia } \\
\hline \multirow[t]{2}{*}{ Horizon } & \multicolumn{2}{|c|}{ Natural Gas } & \multicolumn{2}{|c|}{ Oil } & \multicolumn{2}{|c|}{ Tin } & \multicolumn{2}{|c|}{ Coal } & \multicolumn{2}{|c|}{ Tin } & \multicolumn{2}{|c|}{ Natural Gas } \\
\hline & $1 S D$ & 2SD & $1 S D$ & $2 S D$ & 1SD & $2 S D$ & $1 S D$ & $2 S D$ & 1SD & $2 S D$ & 1SD & 2SD \\
\hline 0 & 0.703 & 0.713 & 0.680 & 0.686 & 0.031 & 0.026 & 0.413 & 0.409 & 0.683 & 0.678 & 0.341 & 0.358 \\
\hline 1 & 0.122 & 0.149 & 0.599 & 0.621 & 0.065 & 0.052 & 0.704 & 0.698 & 0.860 & 0.865 & 0.634 & 0.654 \\
\hline 2 & 0.234 & 0.278 & 0.795 & 0.812 & 0.133 & 0.113 & 0.759 & 0.754 & 0.948 & 0.948 & 0.787 & 0.803 \\
\hline 3 & 0.369 & 0.425 & 0.869 & 0.880 & 0.232 & 0.192 & 0.864 & 0.866 & 0.984 & 0.984 & 0.899 & 0.910 \\
\hline 4 & 0.500 & 0.565 & 0.925 & 0.937 & 0.328 & 0.281 & 0.932 & 0.932 & 0.996 & 0.996 & 0.953 & 0.958 \\
\hline 5 & 0.534 & 0.606 & 0.963 & 0.967 & 0.439 & 0.390 & 0.966 & 0.967 & 0.999 & 0.999 & 0.971 & 0.978 \\
\hline 6 & 0.650 & 0.714 & 0.975 & 0.978 & 0.426 & 0.368 & 0.985 & 0.986 & 1.000 & 1.000 & 0.988 & 0.991 \\
\hline 7 & 0.748 & 0.804 & 0.984 & 0.987 & 0.528 & 0.472 & 0.994 & 0.994 & 1.000 & 1.000 & 0.994 & 0.996 \\
\hline 8 & 0.794 & 0.853 & 0.990 & 0.992 & 0.625 & 0.569 & 0.997 & 0.997 & 1.000 & 1.000 & 0.998 & 0.998 \\
\hline 9 & 0.848 & 0.891 & 0.995 & 0.996 & 0.713 & 0.661 & 0.998 & 0.998 & 1.000 & 1.000 & 0.999 & 0.999 \\
\hline 10 & 0.877 & 0.918 & 0.998 & 0.998 & 0.626 & 0.629 & 0.999 & 0.999 & 1.000 & 1.000 & 1.000 & 1.000 \\
\hline 11 & 0.886 & 0.940 & 0.999 & 0.999 & 0.670 & 0.630 & 1.000 & 1.000 & 1.000 & 1.000 & 1.000 & 1.000 \\
\hline 12 & 0.892 & 0.945 & 1.000 & 1.000 & 0.742 & 0.707 & 1.000 & 1.000 & 1.000 & 1.000 & 1.000 & 1.000 \\
\hline & & Azer & ijan & & & & & & & & & \\
\hline Horizon & Natu & al Gas & & & & & & & & & & \\
\hline & $1 S D$ & $2 S D$ & 1SD & $2 S D$ & & & & & & & & \\
\hline 0 & 0.116 & 0.125 & 0.279 & 0.300 & & & & & & & & \\
\hline 1 & 0.016 & 0.013 & 0.544 & 0.582 & & & & & & & & \\
\hline 2 & 0.011 & 0.009 & 0.089 & 0.083 & & & & & & & & \\
\hline 3 & 0.025 & 0.022 & 0.013 & 0.008 & & & & & & & & \\
\hline 4 & 0.049 & 0.042 & 0.025 & 0.015 & & & & & & & & \\
\hline 5 & 0.064 & 0.055 & 0.040 & 0.023 & & & & & & & & \\
\hline 6 & 0.029 & 0.020 & 0.057 & 0.038 & & & & & & & & \\
\hline 7 & 0.030 & 0.028 & 0.089 & 0.057 & & & & & & & & \\
\hline 8 & 0.030 & 0.029 & 0.132 & 0.088 & & & & & & & & \\
\hline 9 & 0.041 & 0.041 & 0.160 & 0.109 & & & & & & & & \\
\hline 10 & 0.040 & 0.040 & 0.217 & 0.153 & & & & & & & & \\
\hline 11 & 0.041 & 0.043 & 0.282 & 0.201 & & & & & & & & \\
\hline 12 & 0.116 & 0.125 & 0.279 & 0.300 & & & & & & & & \\
\hline
\end{tabular}

$\mathrm{SD}=$ standard deviation.

Note: Numbers in cells denote $p$-values.

Source: Authors' estimates. 
The Impact of a People's Republic of China Slowdown on Commodity Prices and Detecting the Asymmetric Responses of Economic Activity in Asian Countries to Commodity Price Shocks | 17

Given that we find asymmetric responses for three possible pairs, we proceed to report the results of the impulse response analysis. The results are shown in Table 7 below.

Table 7: Impulse Responses of the Asymmetric Model

\begin{tabular}{|c|c|c|c|c|c|c|c|c|c|c|c|c|}
\hline \multirow{3}{*}{ Horizon } & \multicolumn{8}{|c|}{ Azerbaijan } & \multicolumn{4}{|c|}{ Malaysia } \\
\hline & \multicolumn{4}{|c|}{ Oil } & \multicolumn{4}{|c|}{ Natural Gas } & \multicolumn{4}{|c|}{ Tin } \\
\hline & $+1 S D$ & $+2 S D$ & $-1 S D$ & $-2 S D$ & $+1 S D$ & $+2 S D$ & $-1 S D$ & $-2 S D$ & $+1 S D$ & $+2 S D$ & $-1 S D$ & $-2 S D$ \\
\hline 0 & 3.642 & 9.884 & -2.521 & -2.127 & 1.976 & 6.061 & -1.523 & -1.528 & 4.203 & 10.218 & -2.782 & -2.527 \\
\hline 1 & 4.336 & 11.498 & -3.243 & -3.361 & 2.546 & 7.751 & -2.147 & -2.463 & 5.190 & 12.477 & -3.710 & -4.021 \\
\hline 2 & 4.796 & 12.578 & -3.805 & -4.380 & 2.847 & 8.435 & -2.450 & -2.955 & 5.496 & 13.097 & -4.027 & -4.577 \\
\hline 3 & 5.081 & 13.105 & -4.114 & -5.018 & 3.462 & 9.770 & -3.055 & -3.964 & 5.581 & 13.267 & -4.116 & -4.750 \\
\hline 4 & 4.577 & 12.055 & -3.649 & -4.237 & 3.629 & 10.010 & -3.252 & -4.451 & 5.611 & 13.323 & -4.144 & -4.805 \\
\hline 5 & 4.742 & 12.818 & -3.640 & -3.763 & 3.761 & 10.395 & -3.351 & -4.588 & 5.619 & 13.339 & -4.152 & -4.821 \\
\hline 6 & 4.772 & 12.747 & -3.738 & -4.075 & 4.170 & 11.471 & -3.741 & -5.246 & 5.622 & 13.344 & -4.155 & -4.827 \\
\hline 7 & 4.653 & 12.514 & -3.632 & -3.872 & 4.406 & 11.925 & -3.998 & -5.732 & 5.623 & 13.346 & -4.155 & -4.828 \\
\hline 8 & 4.688 & 12.573 & -3.662 & -3.930 & 4.442 & 11.962 & -4.031 & -5.815 & 5.623 & 13.346 & -4.156 & -4.829 \\
\hline 9 & 4.607 & 12.373 & -3.606 & -3.868 & 4.551 & 12.171 & -4.141 & -6.050 & 5.623 & 13.346 & -4.156 & -4.829 \\
\hline 10 & 4.645 & 12.543 & -3.601 & -3.757 & 4.671 & 12.417 & -4.262 & -6.307 & 5.623 & 13.346 & -4.156 & -4.829 \\
\hline 11 & 4.693 & 12.613 & -3.663 & -3.907 & 4.743 & 12.584 & -4.327 & -6.426 & 5.623 & 13.346 & -4.156 & -4.829 \\
\hline 12 & 4.664 & 12.537 & -3.644 & -3.896 & 4.823 & 12.758 & -4.406 & -6.570 & 5.623 & 13.346 & -4.156 & -4.829 \\
\hline
\end{tabular}

$\mathrm{SD}=$ standard deviation

Notes: Numbers in bold denote significance at the 10\% level. A 1 SD shock for oil is $8.37 \%$, for aluminium $5 \%$, tin $6.52 \%$, coal $6.5 \%$, natural gas $5.87 \%$. A positive SD shock is connoted by (+), and a negative shock by $(-)$.

Source: Authors' estimates.

The most significant response is found for Azerbaijan when responding to a positive and negative shock in natural gas prices. A 1 positive standard deviation shock to oil prices $(5.87 \%)$ leads to a cumulative response in industrial production of 4.8 percentage points over 1 year which is found to be statistically different from a negative response of a decline in 4.4 percentage points over the same time period. For a larger shock (2 standard deviations) the cumulative response over the same time period of 1 year is recorded at 12.75 percentage points for a positive shock, however, for a negative shock, the response is a 6.57 percentage point decline. Azerbaijan is also found to respond asymmetrically to a 1 standard deviation shock in oil prices. A positive shock leads to a cumulative response in industrial production of 4.6 percentage points over approximately 7 months, which is statistically different from a negative response of a decline in 3.6 percentage points over the same time period. The larger shock of 2 standard deviations evokes a significantly different response in terms of magnitude.

Finally, where no evidence of asymmetry is found, a linear model of impulse response functions is employed. We find that there is no significant response of a growth/decline in industrial production due to a 1 standard deviation shock in commodity prices. Out of the 20 commodity /country pairs, we find no significant responses for 14 such pairs for the entire time horizon (12 months). For the remaining six pairs, there is a less than $1 \%$ significant response that is short-lived in most cases. The longest being Indonesia and Malaysia where the shock is found to be significant for up to 4 months after the shock. For Kazakhstan, the responses to a shock in oil, iron, and copper prices, last for 2 months, that is, the shock is found to be significant from the impact period following into the second month after the shock. The results are shown in Table 8. 
Table 8: Impulse Responses of the Symmetric Model

\begin{tabular}{cccc|cccc|ccc|cc}
\hline & \multicolumn{3}{c|}{ Mongolia } & \multicolumn{3}{c|}{ Kazakhstan } & \multicolumn{3}{c|}{ Indonesia } & \multicolumn{2}{c}{ Malaysia } \\
\cline { 2 - 11 } Horizon & Coal & Copper & Iron & Oil & Iron & Copper & Coal & Tin & Gas & Gas & Oil \\
\hline 0 & 0.216 & -0.436 & 0.182 & 0.223 & -0.055 & 0.264 & -0.013 & 0.162 & -0.174 & 0.357 & 0.359 \\
1 & -0.059 & 0.660 & 0.072 & 0.364 & -0.234 & 0.332 & -0.099 & 0.017 & 0.636 & 0.306 & 0.617 \\
2 & -0.014 & 0.506 & 0.118 & 0.398 & -0.225 & 0.370 & -0.099 & 0.121 & 0.063 & 0.349 & 0.616 \\
3 & -0.056 & 0.653 & 0.099 & 0.410 & -0.227 & 0.386 & -0.116 & 0.111 & 0.215 & 0.337 & 0.646 \\
4 & -0.047 & 0.621 & 0.107 & 0.414 & -0.227 & 0.393 & -0.116 & 0.093 & 0.311 & 0.343 & 0.641 \\
5 & -0.054 & 0.642 & 0.104 & 0.415 & -0.227 & 0.396 & -0.119 & 0.113 & 0.197 & 0.341 & 0.646 \\
6 & -0.052 & 0.636 & 0.105 & 0.415 & -0.227 & 0.397 & -0.119 & 0.108 & 0.243 & 0.342 & 0.644 \\
7 & -0.053 & 0.639 & 0.105 & 0.415 & -0.227 & 0.398 & -0.119 & 0.105 & 0.251 & 0.341 & 0.645 \\
8 & -0.053 & 0.638 & 0.105 & 0.415 & -0.227 & 0.398 & -0.119 & 0.109 & 0.230 & 0.341 & 0.645 \\
9 & -0.053 & 0.639 & 0.105 & 0.415 & -0.227 & 0.398 & -0.119 & 0.108 & 0.242 & 0.341 & 0.645 \\
10 & -0.053 & 0.639 & 0.105 & 0.415 & -0.227 & 0.398 & -0.119 & 0.108 & 0.241 & 0.341 & 0.645 \\
11 & -0.053 & 0.639 & 0.105 & 0.415 & -0.227 & 0.398 & -0.119 & 0.108 & 0.237 & 0.341 & 0.645 \\
12 & -0.053 & 0.639 & 0.105 & 0.415 & -0.227 & 0.398 & -0.119 & 0.108 & 0.240 & 0.341 & 0.645 \\
\hline
\end{tabular}

Notes: Numbers in bold denote significance levels. A 1 standard deviation shock for oil is $8.37 \%$, for aluminium $5 \%$, tin $6.52 \%$, coal $6.5 \%$, natural gas $5.87 \%$, iron $8.31 \%$, copper $6.8 \%$, nickel $8.95 \%$, zinc $6.02 \%$.

Source: Authors' estimates.

The results broadly conclude that there is no significant response of any growth decline in industrial production following a price shock. The responses are mostly insignificant, and where significance is found, the shocks are not persistent, dissipating within 2 months following the shock and lie between approximately 0.1 and 0.65 in magnitude.

\section{CONCLUSION}

In this paper, we make two separate analyses. First, we estimate the impact on commodity prices as a result of a slowdown in economic activity in the PRC. We then measure whether there is a significant difference in the response of growth in selected developing Asian economies to a positive shock as opposed to a negative shock in commodity prices.

We make a contribution to the literature in two ways. First, we separately model the behavior of individual commodity prices to a slowdown in the PRC, as it is already noted in previous studies that different commodity price dynamics can be different. This is true even for commodities that may be related to each other such as metals. In this way we depart from a significant set of studies that have used a common indicator for commodities or have used an aggregate commodity price index for metals and minerals separately. Secondly, we take into account the fact that commodity prices are characterized by structural breaks and to this end we make use of novel econometric procedures to account for breaks in the variables. The first part of the analysis makes use of VAR estimation incorporating the Flexible Fourier Form due to Enders and Jones (2016).

When considering the effect of a 1 percentage point slowdown in the PRC economy, we find that the different metal prices respond in varying degrees both in magnitude and the length of time for which the persistence of the shock is found to exist. For example, the highest significant response is found for tin lasting about three quarters, whereas for zinc, the response is relatively muted and the impact of the shock lasts only for one quarter. The same variation is found in energy commodities where the response for coal is highest and the response of natural gas is approximately a third in magnitude to that of coal, and the response of crude oil around half. 
The Impact of a People's Republic of China Slowdown on Commodity Prices and Detecting the Asymmetric Responses of Economic Activity in Asian Countries to Commodity Price Shocks | 19

While commodity prices saw an increasing trend during the time when the PRC experienced strong growth, it is not surprising that a slowdown in the PRC economic activity would reverse the trend in commodity prices. However, the analysis shows that the response to a slowdown would lead to potential declines of commodity prices in varying degrees of magnitude. While for metals, the price decline has been more variable ranging between $2.5 \%$ to a little over $20 \%$, for energy commodities the decline ranges between $4.4 \%$ and $11.5 \%$. A possible reason for the varying decline in different commodity prices due to a slowdown in the PRC economic activity might be the fact that the shares of the PRC consumption for these individual commodities is quite different (see Appendix Table A.1). The share of tin, coal, and aluminium as a percentage of world consumption is well over $40 \%$, which can be a contributory factor for the sharp decline in these commodity prices. However, the same is not true for zinc; however, given that the zinc mining sector in the PRC is huge, accounting for about $40 \%$ of the world's mine supply and the industry is nebulous and its cost structure little understood, the relatively low response to a PRC growth slowdown may not be that surprising (Financial Times 2015).

Commodity prices are known to be highly volatile and are characterized by flat bottoms punctuated by sharp spikes. As a result, developing countries that are heavily dependent on commodities as their main source of income and at the same time are closely linked to the PRC as their main export destination, are likely to be affected by the unpredictable swings in commodity prices. The second part of this study determines whether the economic growth in five selected developing Asian countries that are heavily dependent on commodities respond in an asymmetric manner to positive commodity price shocks as opposed to negative price shocks. For this part we adopt the method of structural dynamic regression due to Kilian and Vigfusson (2011) to allow for the correct form of censoring to separate positive and negative shocks. Apart from Azerbaijan, and to a lesser extent Malaysia, there is no evidence of any asymmetric response of economic activity to positive and negative commodity price shocks.

In the case of Azerbaijan, the magnitude of responses to a relatively large shock leads to a significant difference as opposed to a smaller shock. ' The difference in magnitude of Malaysia in response to tin price shocks is more prominent. This implies that for both Azerbaijan and Malaysia, economic growth from a positive shock is likely to be higher than a slump from a negative shock. Therefore the negative impact that oil prices, tin prices, and the slowdown of the PRC may have on a country like Malaysia is not all doom and gloom provided that the PRC growth recovers, oil prices start climbing along with price increases in key commodities such as tin. For Azerbaijan, it is not surprising that oil price booms have contributed to significant increases in growth. While the decline in oil prices has had a significant impact on the economy of Azerbaijan, the decline has not been severe, partly explained by the diversification into industry and agriculture in recent years in an attempt to reduce their dependency on oil and more recently, a boost in capital expenditure by the government (Asian Development Bank 2015). For the other countries, such as Kazakhstan, Mongolia, and Indonesia, there is no evidence of any major impact on their economies (i.e., industrial production) as a result of commodity price shocks. Some response is found to exist in the case of Malaysia for oil and natural gas shocks, and Kazakhstan for copper. However, in all cases, the response is less than 1 percentage point resulting solely from commodity prices.

Our results show that with regard to economic activity for countries such as Azerbaijan, in response to oil and natural gas price shocks as well as Malaysia, in response to tin price shocks, the growth decline is significant. Stabilization policies to smooth income flows are found to be effective

1 The case of Azerbaijan would need to be treated with some caution as the sample size in the analysis was significantly smaller with the data starting from January 2009. 
when shocks to commodity prices are transitory in nature. However, if the shocks are persistent and long-lived then such policies can be difficult to implement. Maintaining buffer stocks can be useful but for commodities such as tin, they are not maintained any longer. Economies that experience a current account deficit as a result of lost export earnings can compensate this deficit by allowing for a capital account surplus driven by increased public and private borrowing. With this strategy, there is the risk of a revenue shortfall during the period when the repayments are anticipated to be quite high (Newbold, Pfaffenzeller, and Rayner 2005). Policy makers in many countries that are exporters of primary commodities have moved toward policies that facilitate smoothing the macroeconomic effects of commodity price dynamics, which include introducing fiscal policies that are less procyclical, more flexible exchange rates (although this would depend on what type of exchange rate target countries are pursuing and their inflation targets), and deepening financial systems. These policies could limit the effect of negative commodity price shocks on economic growth. Proceeds of commodity exports could be used to establish sovereign wealth funds that are transparent in order to enable investing in assets that lead to a healthy rate of return. Finally, multilateral institutions have promoted export diversification into other primary commodities. This diversification of exports has been particularly encouraged away from those exports that are in oversupply. Adopting this policy would depend on existing and potential resource availability and possible export destinations. 


\section{APPENDIX}

Table A.1: PRC's Share of Selected Global Commodities, 2000-2014

\begin{tabular}{lcc}
\hline & $\begin{array}{c}\text { Consumption as a Share of World } \\
\text { Consumption, } \%\end{array}$ & $\begin{array}{c}\text { Imports as a Share of World } \\
\text { Imports, \% }\end{array}$ \\
\hline Coal & 50.1 & 17.9 \\
Tin & 47.3 & 8.7 \\
Zinc & 44.7 & 12.0 \\
Copper & 43.9 & 30.7 \\
Aluminium & 43.9 & 6.5 \\
Nickel & 43.7 & 27.6 \\
Oil & 11.3 & 10.1 \\
Natural gas & 4.5 & 4.5 \\
\hline
\end{tabular}

PRC = People's Republic of China.

Sources: UN Comtrade, BP Statistical Review 2015 (both accessed 7 December 2015), and World Bureau of Metal Statistics.

Table A.2: Selected Developing Asian Economies and Their Main Primary Exports, 2013

\begin{tabular}{lccl}
\hline \multicolumn{1}{c}{$\begin{array}{c}\text { Exports of Primary } \\
\text { Developing Asian }\end{array}$} & $\begin{array}{c}\text { Commodities to the } \\
\text { ERC/Total Exports to the } \\
\text { PRomies }\end{array}$ & $\begin{array}{c}\text { Net Export of Primary } \\
\text { Commodities to } \\
\text { PRC (\%) }\end{array}$ & $\begin{array}{c}\text { Major Primary Export } \\
\text { Commodities to World }\end{array}$ \\
\hline Azerbaijan & 57.8 & 29.3 & Oil, natural gas \\
Kazakhstan & 85.7 & 28.8 & Oil, iron, copper \\
Mongolia & 98.7 & 15.9 & Copper, coal, oil \\
Malaysia & 34.4 & 8.7 & Natural gas, oil, tin \\
Indonesia & 79.3 & 4.7 & Coal, tin, natural gas \\
\hline
\end{tabular}

GDP = gross domestic product, $\mathrm{PRC}=$ People's Republic of China .

Note: Country i's net export of primary commodities to world = (exports to world primary commodities - imports from world primary commodities $_{\text {) }}$ $\left.\mathrm{GDP}_{\text {countryi }}\right)^{*} 100$

Sources: UN Comtrade and Haver Analytics.

Table A.3: Structural Break Tests

\begin{tabular}{lcc}
\hline & Break Date 1 & Break Date 2 \\
\hline Aluminium & October 2002 & August 2008 \\
Tin & July 2003 & October 2010 \\
Copper & October 2002 & March 2006 \\
Zinc & May 2003 & September 2009 \\
Oil & October 2008 & January 2012 \\
Gas & June 2001 & January 2009 \\
Iron & December 2004 & February 2010 \\
Coal & January 2007 & December 2009 \\
\hline
\end{tabular}

Source: Authors' estimates. 
Table A.4: Probability Values for Testing the Null of Symmetry

\begin{tabular}{|c|c|c|c|c|c|c|c|c|}
\hline \multirow[b]{2}{*}{ Horizon } & \multicolumn{2}{|c|}{ Aluminium } & \multicolumn{2}{|c|}{ Tin } & \multicolumn{2}{|c|}{ Copper } & \multicolumn{2}{|c|}{ Zinc } \\
\hline & $1 S D$ & $2 S D$ & $1 S D$ & $2 S D$ & 1SD & $2 S D$ & 1SD & $2 S D$ \\
\hline 0 & 1.000 & 0.365 & 1.000 & 0.885 & 0.978 & 0.314 & 1.000 & 0.282 \\
\hline 1 & 0.997 & 0.199 & 1.000 & 0.649 & 0.998 & 0.490 & 0.996 & 0.534 \\
\hline 2 & 1.000 & 0.355 & 0.999 & 0.818 & 1.000 & 0.515 & 1.000 & 0.542 \\
\hline 3 & 0.999 & 0.482 & 1.000 & 0.916 & 1.000 & 0.680 & 0.993 & 0.689 \\
\hline 4 & 1.000 & 0.628 & 1.000 & 0.960 & 1.000 & 0.803 & 0.998 & 0.813 \\
\hline 5 & 1.000 & 0.723 & 1.000 & 0.982 & 1.000 & 0.883 & 1.000 & 0.885 \\
\hline 6 & 0.999 & 0.714 & 1.000 & 0.992 & 1.000 & 0.912 & 1.000 & 0.932 \\
\hline 7 & 0.999 & 0.775 & 1.000 & 0.997 & 1.000 & 0.950 & 1.000 & 0.956 \\
\hline 8 & 1.000 & 0.826 & 1.000 & 0.986 & 1.000 & 0.971 & 1.000 & 0.965 \\
\hline 9 & 1.000 & 0.884 & 1.000 & 0.993 & 1.000 & 0.985 & 1.000 & 0.980 \\
\hline 10 & 1.000 & 0.920 & 1.000 & 0.997 & 1.000 & 0.989 & 1.000 & 0.990 \\
\hline 11 & 1.000 & 0.924 & 1.000 & 0.999 & 1.000 & 0.990 & 1.000 & 0.993 \\
\hline 12 & 1.000 & 0.939 & 1.000 & 0.999 & 1.000 & 0.994 & 1.000 & 0.996 \\
\hline \multirow[t]{2}{*}{ Horizon } & \multicolumn{2}{|c|}{ Oil } & \multicolumn{2}{|c|}{ Natural Gas } & \multicolumn{2}{|c|}{ Iron } & \multicolumn{2}{|c|}{ Coal } \\
\hline & $1 S D$ & $2 S D$ & 1SD & $2 S D$ & 1SD & $2 S D$ & 1SD & $2 S D$ \\
\hline 0 & 1.000 & 0.148 & 1.000 & 0.823 & 1.000 & 0.238 & 1.000 & 0.213 \\
\hline 1 & 0.994 & 0.215 & 1.000 & 0.488 & 0.989 & 0.485 & 0.872 & 0.459 \\
\hline 2 & 0.999 & 0.364 & 0.985 & 0.674 & 0.991 & 0.591 & 0.965 & 0.588 \\
\hline 3 & 1.000 & 0.475 & 0.996 & 0.762 & 0.998 & 0.752 & 0.975 & 0.688 \\
\hline 4 & 1.000 & 0.608 & 0.999 & 0.867 & 0.996 & 0.860 & 0.991 & 0.617 \\
\hline 5 & 1.000 & 0.703 & 1.000 & 0.927 & 0.999 & 0.896 & 0.992 & 0.680 \\
\hline 6 & 1.000 & 0.800 & 1.000 & 0.961 & 1.000 & 0.940 & 0.997 & 0.783 \\
\hline 7 & 1.000 & 0.865 & 1.000 & 0.982 & 1.000 & 0.969 & 0.998 & 0.850 \\
\hline 8 & 1.000 & 0.909 & 1.000 & 0.987 & 1.000 & 0.978 & 0.999 & 0.898 \\
\hline 9 & 1.000 & 0.927 & 1.000 & 0.975 & 0.999 & 0.989 & 1.000 & 0.937 \\
\hline 10 & 1.000 & 0.995 & 1.000 & 0.987 & 1.000 & 0.995 & 1.000 & 0.959 \\
\hline 11 & 1.000 & 0.972 & 1.000 & 0.992 & 0.999 & 0.998 & 1.000 & 0.977 \\
\hline 12 & 1.000 & 0.967 & 1.000 & 0.996 & 0.999 & 0.999 & 1.000 & 0.987 \\
\hline
\end{tabular}

$\mathrm{SD}=$ standard deviation

Notes: The results show that for the above commodities we cannot reject the null (All p-values are found to be greater than 0.1 ; i.e., $10 \%$ significance level). No evidence of asymmetry is concluded.

Source: Authors' estimates. 


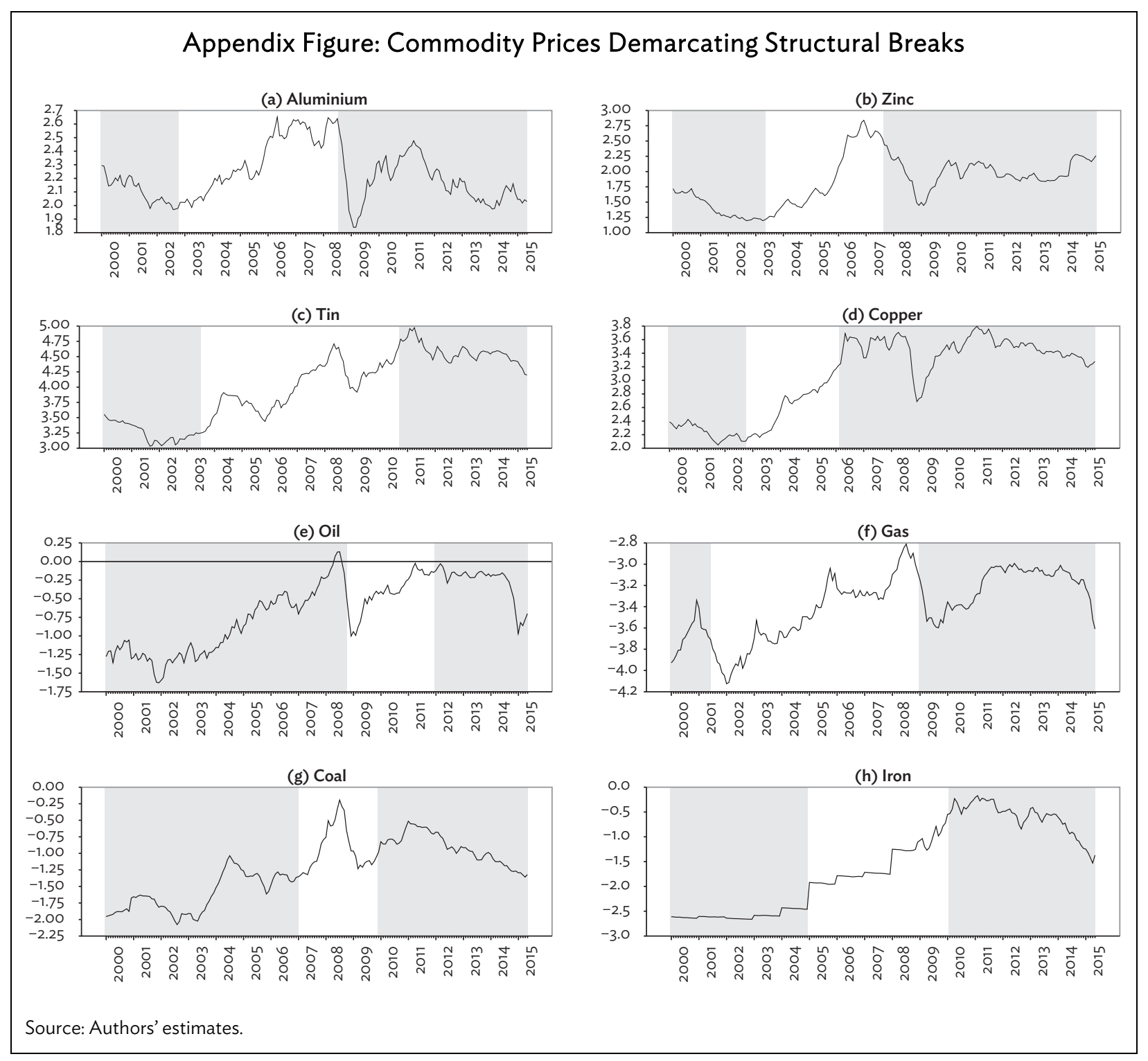




\section{REFERENCES*}

Addison, Tony, Atanu Ghoshray, and Michalis P. Stamatogiannis. 2016. "Agricultural Commodity Price Shocks and Their Effect on Growth in Sub-Saharan Africa." Journal of Agricultural Economics 67 (1): 47-61.

Ahuja, Ashvin, and Malhar Nabar. 2012. "Investment-Led Growth in China: Global Spillovers.” IMF Working Paper WP/12/267.

Arbatli, Elif C., and Garima Vasishtha. 2012. "Growth in Emerging Market Economies and the Commodity Boom of 2003-2008: Evidence from Growth Forecast Revisions." Bank of Canada Working Paper 2012-8.

Asian Development Bank (ADB). 2015. Asian Development Outlook 2015 Update: Enabling Women Energizing Asia. Manila.

Astill, Sam, David Harvey, Stephen Leybourne, A. M. Robert Taylor. 2015. "Robust and Powerful Tests for Nonlinear Deterministic Components." Oxford Bulletin of Economics and Statistics 77 (6): 780-99.

Bai, Jushan, and Pierre Perron. 1998. Estimating and Testing Linear Models with Multiple Structural Changes. Econometrica 66 (1): 47-78.

- 2003. "Computation and Analysis of Multiple Structural Change Models." Journal of Applied Econometrics 18 (1): 1-22.

Balagtas, Joseph, and Matthew T. Holt. 2009. "The Commodity Terms of Trade, Unit Roots, and Nonlinear Alternatives: A Smooth Transition Approach.” American Journal of Agricultural Economics 91 (1): 87-105.

Becker, Ralf, Walter Enders, and Stan Hurn. 2004. “A General Test for Time Dependence Parameters.” Journal of Applied Econometrics 19 (7): 899-906.

Broda, Christian. 2004. "Terms of Trade and Exchange Rate Regimes in Developing Countries." Journal of International Economics 63 (1): 31-58.

Cashin, Paul, C. John McDermott, and Catherine Pattillo. 2004. "Terms of Trade Shocks in Africa: Are They Short-Lived or Long-Lived?" Journal of Development Economics 73 (2): 727-44.

Cheung, Calista, and Sylvie Morin. 2007. "The Impact of Emerging Asia on Commodity Prices." Bank of Canada Working Paper 2007-55.

Collier, Paul, and Benedikt Goderis. 2012. Commodity Prices and Growth: An Empirical Investigation. European Economic Review 56 (6): 1241-60.

Collier, Paul, and Jan Willem Gunning. 1999. Why Has Africa Grown Slowly? Journal of Economic Perspectives 13 (3): 3-22.

\footnotetext{
* ADB recognizes "China” as the People's Republic of China.
} 
Deaton, Angus, and Guy Laroque. 1992. "On the Behaviour of Commodity Prices." Review of Economic Studies. 59 (1): 1-23.

- 2003. "A Model of Commodity Prices after Sir Arthur Lewis." Journal of Development Economics 71 (2): 289-310.

Deaton, Angus, and Ron Miller. 1996. "International Commodity Prices, Macroeconomic Performance and Politics in Sub-Saharan Africa." Journal of African Economies 5 (3): 99-191.

Dehn, Jan. 2000. "Commodity Price Uncertainty in Developing Countries." Centre for the Study of African Economies WPS/2000-12.

Elekdag, Selim, René Lalonde, Douglas Laxton, Dirk Muir, and Paolo Pesenti. 2007. "Oil Price Movements and the Global Economy: A Model-Based Assessment." Bank of Canada Working Paper 2007-34.

Enders, Walter, and Paul Jones. 2016. "Grain Prices, Oil Prices, and Multiple Smooth Breaks in a VAR." Studies in Nonlinear Dynamics and Econometrics (forthcoming).

Enders, Walter, and Junsoo Lee. 2012. "A Unit Root Test Using a Fourier Series to Approximate Smooth Breaks." Oxford Bulletin of Economics and Statistics 74 (4): 574-99.

Financial Times. 2015. "Commodity Prices Slide on China's Weakness." October 19. http://www.ft.com/cms/s/0/c783877a-765a-11e5-933d-efcdc3c11c89.html\#axzz49XEtH6Dj

Frankel, Jeffrey. 2008. "The Effect of Monetary Policy on Real Commodity Prices." In Asset Prices and Monetary Policy, edited by John Y. Campbell, 291-327. Chicago and London: University of Chicago Press.

Frankel, Jeffrey, and Andrew Rose. 2009. "Determinants of Agricultural and Mineral Commodity Prices." Kennedy School of Government, Harvard University. Mimeo.

Gallant, A. Ronald. 1981. "On the Bias in Flexible Functional Forms and an Essentially Unbiased Form." Journal of Econometrics 5 (2): 211-45.

Gauvin, Ludovic, and Cyril Rebillard. 2015. Towards Recoupling? Assessing the Global Impact of a Chinese Hard Landing through Trade and Commodity Price Channels. Bank of France Working Paper No. 562.

Ghoshray, Atanu. 2011. "A Reexamination of Trends in Primary Commodity Prices." Journal of Development Economics 95 (2): 242-51.

Ghoshray, Atanu, Mohitosh Kejriwal, and Mark Wohar. 2014. "Breaks, Trends and Unit Roots in Commodity Prices: A Robust Investigation." Studies in Nonlinear Dynamics and Econometrics 18 (1): $23-40$.

Ghoshray, Atanu, and Ashira Perera. 2016. "An Empirical Study of Commodity Prices after Sir Arthur Lewis." The Manchester School 84 (4): 551-71. 
Harvey, David I., Stephen J. Leybourne, and A. M. Robert Taylor. 2010. "Robust Methods for Detecting Multiple Level Breaks in Autocorrelated Time Series.” Journal of Econometrics 157 (2): 342-58.

Juselius, Katarina, Niels Framroze Møller, and Finn Tarp. 2014. "The Long-Run Impact of Foreign Aid in 36 African Countries: Insights from Multivariate Time Series Analysis." Oxford Bulletin of Economics and Statistics 76 (2): 153-84.

Kellard, Neil, and Mark Wohar. 2006. "On the Prevalence of Trends in Primary Commodity Prices." Journal of Development Economics 79 (1): 146-67.

Kilian, Lutz. 2014. "Oil Price Shocks: Causes and Consequences." Annual Review of Resource Economics $6(1): 133-54$.

Kilian, Lutz, and Robert John Vigfusson. 2009. "Pitfalls in Estimating Asymmetric Effects of Energy Price Shocks." CEPR Discussion Papers 7284.

2011. "Are the Responses of the U.S. Economy Asymmetric in Energy Price Increases and Decreases?” Quantitative Economics 2 (3): 419-53.

Klotz, Philipp, Tsoyu Calvin Lin, and Shih-Hsun Hsu. 2014. Global Commodity Prices, Economic Activity and Monetary Policy: The Relevance of China. Resources Policy 42 (December): 1-9.

Mork, Knut Anton. 1989. "Oil and the Macroeconomy When Prices Go Up and Down: An Extension of Hamilton's Results." Journal of Political Economy 97 (3): 740-44.

Newbold, Paul, Stephan Pfaffenzeller, and Anthony Rayner. 2005. "How Well are Long Run Commodity Price Series Characterised by Trend Components?" Journal of International Development 17 (4): 479-94.

Ng, Serena, and Timothy Vogelsang. 2002. "Analysis of Vector Autoregressions in the Presence of Shifts in Mean." Econometric Reviews 21 (3): 353-81.

Perron, Pierre. 1989. "The Great Crash, The Oil Price Shock and the Unit Root Hypothesis." Econometrica 57 (6): 1361-401.

Pesaran, M. Hashem, L. Vanessa Smith, and Ron Smith. 2007. "What if the UK or Sweden Had Joined the Euro in 1999? An Empirical Evaluation Using a Global VAR." International Journal of Finance and Economics 12 (1): 55-87.

Pesaran, M. Hashem, and Ron Smith. 1995. "Estimating Long Run Relations from Dynamic Heterogeneous Panels." Journal of Econometrics 68 (1): 79-113.

Raddatz, Claudio. 2007. "Are External Shocks Responsible for the Instability in Low Income Countries?" Journal of Development Economics 84 (1): 155-87.

Reuters. 2015. “Azerbaijan sees 1.8 pct GDP growth in 2016, bases budget on $\$ 50$ oil price." October 20. http://uk.reuters.com/article/azerbaijan-budget-idUKL8N12K1IO20151020 
Roache, Shaun. 2012. “China's Impact on World Commodity Prices.” IMF Working Paper WP/12/115.

Roache, Shaun, and Marina Roussett. 2015. "China: Credit, Collateral and Commodity Prices." HKIMR Working Paper No. 27/2015.

Rodrigues, Paulo M. M., and A. M. Robert Taylor. 2012. "The Flexible Fourier Form and Local Generalised Least Squares De-trended Unit Root Tests." Oxford Bulletin of Economics and Statistics 74 (5): 735-59.

Sun, Jingwei, and Wendong Shi. 2015. "Breaks, Trends, and Unit Roots in Spot Prices for Crude Oil and Petroleum Products.” Energy Economics. 50 (July): 169-77.

Varangis, Panos, Sona Varma, Angelique dePlaa, and Vikram Nehru. 2004. "Exogenous Shocks in Low Income Countries: Economic Policy Issues and the Role of the International Community." Background Paper Prepared for the Report: Managing the Debt Risk of Exogenous Shocks in Low Income Countries. World Bank.

Wang, Dabin, and William G. Tomek. 2007. "Commodity Prices and Unit Root Tests." American Journal of Agricultural Economics 89 (4): 873-89.

Zanias, George. 2005. "Testing for Trends in the Terms of Trade between Primary Commodities and Manufactured Goods.” Journal of Development Economics 78 (1): 49-59.

Zivot, Eric, and Donald Andrews. 1992. "Further Evidence on the Great Crash, the Oil Price Shock, and the Unit Root Hypothesis." Journal of Business and Economic Statistics 10 (3): 251-70. 


\section{The Impact of a People's Republic of China Slowdown on Commodity Prices and Detecting the Asymmetric Responses of Economic Activity in Asian Countries to Commodity Price Shocks}

This paper studies the question: How did the slowdown of the People's Republic of China impact commodity prices, and in turn, what were the effects of commodity prices on emerging and developing Asian countries? This study carries out the analysis in two parts. First, noting the fact that commodity prices are characterized by structural breaks, a model based on a Flexible Fourier Form is employed to study the causal relations between a slowdown in the People's Republic of China and different commodity prices. The second part investigates whether the response of emerging and developing Asian countries to a positive or negative shock is significantly different.

\section{About the Asian Development Bank}

ADB's vision is an Asia and Pacific region free of poverty. Its mission is to help its developing member countries reduce poverty and improve the quality of life of their people. Despite the region's many successes, it remains home to half of the world's extreme poor. ADB is committed to reducing poverty through inclusive economic growth, environmentally sustainable growth, and regional integration.

Based in Manila, ADB is owned by 67 members, including 48 from the region. Its main instruments for helping its developing member countries are policy dialogue, loans, equity investments, guarantees, grants, and technical assistance. 